\title{
Factors affecting school performance in children with rheumatic heart disease
}

\section{Reference to educational achievement, absent of school and dropouts}

\author{
Arief Hermanu S, Sudigdo Sastroasmoro, Bambang Madiyono, Ismet N. Oesman \\ Department of Child Health, Medical School University of Indonesia, Cipto Mangunkusumo Hospital, Jakarta
}

\begin{abstract}
The aim of this study was to determine the association between school performance and age, sex, duration of illness, educational achievement prior to illness, socioeconomic status of family, parent's educational level, number of children in the family and severity of the disease of patients with rheumatic heart disease (RHD). Subjects were patients with RHD treated at the Division of Cardiology, Department of Child Health, Cipto Mangunkusumo Hospital Jakarta. The parameters of school performance were educational achievement, absent of school and dropout. All data were processed by using EpiInfo program to find out bivariate analysis and Statistic Program for Social Sciences (SPSS) for multivariate analysis. We obtained 80 patients with RHD; most of them were of mild severity (64 of $80 \%$ ) and the remainder $16(20 \%)$ with severe disease. There were $44(55 \%)$ males and 36 (45\%) females. Most parents (42 or 53\%) had junior high school educational level, most of them, $23(29 \%)$ had elementary school education, and $3(4 \%)$ illiterate. Bivariate and multivariate analyses showed that severity of disease and parental educational level were associated withschool performance of patients with $\mathrm{RHD}$, but age, sex, duration of disease, premorbid educational achievement, socio-economic level of the family and number of children in family were not. [Paediatr Indones 2001; 41:299-304]
\end{abstract}

Keywords: rheumatic heart disease, school performance, prognosis, parental education

RHEUMATIC HEART DISEASE, ESPECIALLY THE SEVERE ONE IS a serious problem, both for the patient, family and society as well. Unfortunately the disease frequently affects school-age children and productive, active adolescents resulting in negative impacts on growth and development. ${ }^{1}$ Rheumatic heart disease is the leading acquired cardiac disease frequently encountered in childhood and adolescence in many developing countries. Although it can be prevented, the disease still causes high morbidity and mortality. ${ }^{2}$

The prevalence of rheumatic heart disease in Indonesia is sufficiently high, i.e., 0.3-0.8 per 1000 school-age children aged $5-15$ years, ${ }^{3,4}$ with the mor-

Correspondence: Arief Hermanu S, MD, Department of Child Health, Medical School University of Indonesia, Cipto Mangunkusumo Hospital, Jakarta, Tel 62-21-3147342, Fax. 3907743. tality rate of at least 10 times higher compared to that in developed contries. 5,6 This disease is associated with poor nutritional and lower socio-economic status and uneven distribution of health care. ${ }^{3,4} \mathrm{Be}$ sides, rheumatic heart disease will also affect daily activities, educational achievement and absent of school that even may cause dropouts. This reflects how rheumatic heart disease can influence schooling performance. ${ }^{7}$ To the best of our knowledge there is no study concerning schooling performance in students contracting rheumatic heart disease, both in Indonesia and abroad. Among various factors known or suggested as influencing schooling performance in students with RHD are age, sex, family socio-economic status, parental educational level, number of children the family, duration of illness, educational achievement prior to disease, and severity of the dis- 
ease. We aimed to determine factors associated with schooling performance of children with RHD treated in our hospital during the last 9 years.

\section{Methods}

We reviewed patients with RHD visited the outpatient clinic of Cardiology Division, Department of Child Health, Dr. Cipto Mangunkusumo Hospital from 1990 to 1998. Data were obtained from medical records and questionnaire. We collected data for age, sex, socioeconomic status of family, parental educational level, number of children in family, duration of illness, educational achievement prior to illness and severity of the disease. Those data were considered or suggested as risk factors or independent variables, while the dependent variable was school performance possessing 3 parameters, namely educational achievement, absent of school, and dropouts.

The inclusion criteria included (1) patients with rheumatic heart disease visited the outpatient clinic of Division of Cardiology, Department of Child Health between January 1, 1990 and December 31, 1998; (2) age 6-15 years, (3) patients had never transferred to other school during educational period; and (4) the medical record was completed with clear address accompanied by findings on history taking, physical examination, electrocardiographic, chest-x ray, and echocardiography. We excluded patients who died during first quarter before after diagnosis of RHD was established.

\section{Results}

\section{Characteristics of the subjects}

During the study period 80 patients with RHD visited the Division of Cardiology, Department of Child Health, Cipto Mangunkusumo Hospital. Most of patients were in mild disease 64 (80\%) and the other 16 (20\%) with severe disease, 3 cases of 16 subjects with severe disease died less than six months after the diagnosis of RHD was established. The subjects comprised of 44 males (55\%) and females 36 (45\%); most of them (55\%) belonged 12-15 year age group (Table 1).

According to duration of illness, the most prevalent length of disease of more than 2 years was found in $44(55 \%)$ of cases and 36 (45\%) of cases with du-
TABLE 1. DISTRIBUTION OF RHD PATIENTS BY INTERNAL FACTOR AND DISEASE SEVERITY

\begin{tabular}{|c|c|c|c|}
\hline \multirow[t]{2}{*}{ Internal factor } & \multicolumn{2}{|c|}{ Severity of disease } & \multirow{2}{*}{$\begin{array}{c}\text { Number } \\
n(\%) \\
(n=80)\end{array}$} \\
\hline & $\begin{array}{c}\text { Severe }(\%) \\
(n=16)\end{array}$ & $\begin{array}{l}\text { Mild (\%) } \\
(n=64)\end{array}$ & \\
\hline \multicolumn{4}{|l|}{ - Age (yr) } \\
\hline$-6-8$ & $1(6)$ & $7(11)$ & $7(10)$ \\
\hline$-9-11$ & 6 (38) & 22 (34) & 28 (35) \\
\hline$-12-15$ & $9(56)$ & $35(55)$ & $44(55)$ \\
\hline \multicolumn{4}{|l|}{ - Sex } \\
\hline - Male & $11(69)$ & $33(52)$ & $44(55)$ \\
\hline - Female & 5 (31) & $31(48)$ & 36 (45) \\
\hline \multicolumn{4}{|c|}{ - Duration of illness $(\mathrm{yr})$} \\
\hline$-\leq 2$ & $9(56)$ & $27(42)$ & $36(45)$ \\
\hline$->2$ & $7(44)$ & $37(58)$ & $44(55)$ \\
\hline \multicolumn{4}{|c|}{$\begin{array}{l}\text { - School performance } \\
\text { prior to illness: }\end{array}$} \\
\hline - Poor & $0(0)$ & $2(3)$ & $2(3)$ \\
\hline - Good & $16(100)$ & 62 (97) & 78 (97) \\
\hline
\end{tabular}

ration of disease of $<2$ years (Table 1 ). The same table shows distribution of educational achievement prior to illness that good achievement was encountered in 78 (97\%) of patients, whereas poor achievement in $2(3 \%)$ of patients.

On the basis of socio-economic level and the severity of disease (Table 2), the majority of patients (59 or 74\%) came from lower economic status and the remaining 21 (26\%) from middle to higher socioeconomic level. In lower economic status group, most of them were in mild disease (47 or $73 \%$ ) and the remaining $12(75 \%)$ cases were in severe disease.

Distribution of RHD patients by parental educational level and the severity of disease showed that they prevalently came from level $<$ junior high school of $42(53 \%)$ and the remaining 38 (47\%) from above senior high school level (Table 2).

Concerning the number of children in family and the severity of disease, Table 2 shows that the highest figure was observed in family with $>2$ children in 61

TABLE 2. DISTRIBUTION OF RHD PATIENTS BY EXTERNAL FACTOR AND DISEASE SEVERITY

\begin{tabular}{|c|c|c|c|}
\hline \multirow[t]{2}{*}{ External factor } & \multicolumn{2}{|c|}{ Severity of disease } & \multirow{2}{*}{$\begin{array}{c}\text { Number } \\
(80) \\
\text { n (\%) }\end{array}$} \\
\hline & $\begin{array}{l}\text { Severe }(\%) \\
(n=16)\end{array}$ & $\begin{array}{c}\text { Mild (\%) } \\
(\mathrm{n}=64)\end{array}$ & \\
\hline \multicolumn{4}{|c|}{ - Socio-economic status } \\
\hline - Low & 12 & 47 & 59 \\
\hline - High & 4 & 17 & 21 \\
\hline \multicolumn{4}{|c|}{ - Parental educational level } \\
\hline$-\leq \mathrm{JHS}$ & 6 & 36 & 42 \\
\hline$->$ SNR & 10 & 28 & 38 \\
\hline \multicolumn{4}{|c|}{ - Number of child in family } \\
\hline$->2$ & 14 & 47 & 61 \\
\hline$-\leq 2$ & 2 & 17 & 19 \\
\hline
\end{tabular}


(76\%) patients and the other 19 (24\%) with number of children of 2 orless.

Based on valvular defects and the severity of disease, the most commonly found valvular defect was mitral regurgitation (MR) in 37 (46\%) followed by a combination of MR, mitral stenosis (MS) and tricuspid regurgitation (TR) and MR with TR. The majority of MI in 35 (54\%) cases were in mild degree and 5 (33\%) of cases with MI-MS-TI mostly were in severe degree (Table 3).

TABLE 3. DISTRIBUTION OF RHD PATIENTS BY VALVULAR DEFECT AND DISEASE SEVERITY

\begin{tabular}{|c|c|c|c|c|}
\hline \multirow[t]{2}{*}{ Valvular defect } & \multicolumn{2}{|c|}{ Severity of disease } & \multicolumn{2}{|c|}{ Number } \\
\hline & Severe (\%) & Mild (\%) & $\mathrm{n}$ & $(\%)$ \\
\hline M & $2(12)$ & $35(54)$ & 37 & $(46)$ \\
\hline $\mathrm{Al}$ & $0(0)$ & $5(8)$ & 5 & (6) \\
\hline $\mathrm{Ml}-\mathrm{MS}$ & $1(7)$ & $4(6)$ & 5 & (6) \\
\hline $\mathrm{Ml}-\mathrm{Tl}$ & 2 (12) & $5(8)$ & 7 & (9) \\
\hline $\mathrm{Ml}-\mathrm{Al}$ & $0(0)$ & $4(6)$ & 4 & (5) \\
\hline $\mathrm{Ml}-\mathrm{MS}-\mathrm{Tl}$ & $5(32)$ & $2(3)$ & 7 & (9) \\
\hline $\mathrm{Ml}-\mathrm{MS}-\mathrm{Al}$ & 2 (12) & $2(3)$ & 4 & (5) \\
\hline $\mathrm{Ml}-\mathrm{Tl}-\mathrm{Al}$ & $2(12)$ & $3(5)$ & 5 & (6) \\
\hline $\mathrm{Ml}-\mathrm{MS}-\mathrm{Tl}-\mathrm{Al}$ & $2(12)$ & $1(2)$ & 3 & (4) \\
\hline Other & $0(0)$ & $3(5)$ & 3 & (4) \\
\hline Total & $16(100)$ & $64(100)$ & 80 & $(100)$ \\
\hline
\end{tabular}

\section{Bivariate analysis}

Bivariate analysis was used to look for the association of each independent variables and school performance. In this level the association of one independent variable with each dependent variables was counted by ignoring confounding factor, so if an association were existed, it was not necessarily a causal one.

Bivariate analysis between each independent variables and schooling performance showed that there were significant associations between parental educational level $(\mathrm{p}=0,009)$, severity of the disease $(p=0.05)$ and number of children in the family $(p=0.0507)$ with educational achievement $(p=0.009)$. Another independent variable influencing educational achievement was age. On the other hand, sex, duration of illness, educational achievement prior to illness and socioeconomic status of family showed no relation to educational achievement.

There was significant relationship between the severity of disease and dropouts $(p=0.006)$. Indepen- dent variables that were not associated with to dropouts included age, sex, duration of illness, educational achievement prior to illness, socioeconomic state of family, parental educational level and number of children in family.

Overall bivariate analysis between each independent variables and respective dependent variables (educational achievement, absent of school, and dropouts) showed three independent variables providing significance namely parental educational level number of children in family, and the severity of disease. In this study, out of 80 patients with RHD satisfying inclusion criteria, 43 (54\%) of patients showed good educational achievement whereas poor achievement was observed in $37(46 \%)$ of patients (data not shown)

\section{Multivariate analysis}

Following bivariate analysis, multivariate analysis with logistic regression was done to assess the association of each independent variables giving positive significance in bivariate analysis, plus independent variables that theoretically may affect school performance, though proved to be insignificant. In this analysis the dependent variable was school performance while independent variables giving significance in bivariate analysis was severity of the disease (Table 4), whereas other independent variables presumed theoretically relate to schooling performance were age, sex, duration of illness, educational achievement prior to illness, socioeconomic state of family and parental educational level.

Statistically, in this analysis a variety of confounding factors could be ruled out so an association of one independent variable and schooling performance, if any, considered a causal relationship. With this analysis technique the role of each independent variable could, at once, be determined. The type of analysis compatible with these data (nominal-scaled dependent variable and nominal and numeric-scaled independent variables) was logistic regression.

Table 4 showed the result of logistic regression analysis showing association of various independent variables and schooling performance. Out of various independent variables, those actually providing significance in schooling performance were the severity of disease $(p=0.0010)$ and parental educational level $(p=0.0507)$ 
TABLE 4. LOGISTIC REGRESSION ANALYSIS SHOWED ASSOCIATION OF SCHOOLING PERFORMANCE AND VARIOUS INDEPENDENT VARIABLES

\begin{tabular}{|c|c|c|c|c|c|c|c|}
\hline Variable & B & S.E. & Wald & $d f$ & Sig & $\mathrm{R}$ & $\operatorname{Exp}(B)$ \\
\hline Age & ,3360 & ,4049 & ,6885 & 1 & ,4067 &, 0000 & 1,3993 \\
\hline Sex & ,2496 &, 5688 & 1926 & 1 & 6608 & 0000 &, 7791 \\
\hline Duration of illness &,- 0267 &, 5483 &, 0024 & 1 & ,9612 &, 0000 & ,9737 \\
\hline Edu.achieve.prior to illness & 8,0794 & 25,5685 & 0999 & 1 & ,7520 & 0000 & 3227,318 \\
\hline Socio-econ. status of family & ,3563 &, 6746 & ,2789 & 1 &, 5974 &, 0000 & 1,4280 \\
\hline Parental edu.level & 1,1343 &, 5805 & 3,8172 & 1 & 0507 & 1283 & 3,1088 \\
\hline Number of children &,- 0421 & ,6533 &, 0041 & 1 & ,9487 &, 0000 & ,9588 \\
\hline Severity of the disease & 2,5512 & ,7769 & 10,7831 & 1 & 0010 & ,2820 & 12,8228 \\
\hline Constant & $-23,0182$ & 51,1901 & 2022 & 1 & ,6530 & & \\
\hline
\end{tabular}

\section{Discussion}

\section{Characteristics of the subject}

During period of August 1, 1998 until December 31, 1998, 80 patients with RHD visited the Division of Cardiology, Department of Child Health, Cipto Mangunkusumo Hospital. The male to female ratio was $1.2: 1$. This finding differed from the report of Mabilangan's study that showed $82 \%$ rheumatic fever / RHD patients were female. This differentiation is probably due to unevenly distributed sex on sampling. The highest group of $12-15$ years was in 44 (55\%) cases and the lowest of $6-8$ years was in $8(10 \%)$ cases, as seen in Table 1. These data are consistent with statistical report stating that rheumatic fever has high incidence in school-age periode of 5-15 years with its peak in over 10 years. ${ }^{8}$

Some important factors influencing the occurrence of rheumatic fever/RHD are low socio-economic level, crowded population, tropical area with humid climate and sudden changing termperature. ${ }^{9,10}$ One factor which might help reducing rheumatic fever was high economic status. ${ }^{11}$ Our series showed that, most RHD patients came from low socio-economic level of $59(74 \%)$ and 21 (26\%) from high socio-economic status (Table 2).

Valvular defects commonly observed were MI in 37 (46\%) patients, most of them, 35 (54\%), with mild disease and the remaining $2(12 \%)$ with severe disease, as seen in Table 3. This finding is in accordance with the report of most hospitals showing the highest prevalence rate is in $\mathrm{MI},{ }^{12}$ and other study reporting in 61 patients with $\mathrm{MI}$ on 4 37 years follow-up 56 (91.8\%) remained mild, whereas $5(8.2 \%)$ patients developed severe complications. ${ }^{13}$

\section{Factors affecting school performance in children with RHD}

The number of subjects agreed with the minimal sample size required of 74-80, although at the time of home visit some of them had moved and their address could no longer be identified.

\section{Age}

About $90 \%$ of rheumatic fever patients experienced their first attack in the age range of 5-15 years and in this same period also the highest prevalence of RHD . ${ }^{14-15}$ Based on the report and school-age, the study criteria ranging from 6 to 15 years, ages of elementary and junior high school. To omit a bias, age classification was divided into three groups of 6-8 years, 9-11 years and $12-15$ years.

From statistical analysis through bivariate and logistic regression analyses, age was not significantly associated with educational achievement, absent of school, dropouts, or schooling performance.

\section{Sex}

The role of gender in a variety of aspects on RHD and rheumatic fever at the moment is still controversial. Some researchers reported that there was no marked sex difference in RHD and rheumatic fever incidence and prevalence. ${ }^{16}$ This is consistent with the present study that by sex was not associated with educational achievement, absent of school, dropouts and schooling performance as well.

\section{Duration of illness}

Duration of illness in the present study was classified into those with more than 2 or less years duration and those with 2 years or less. This classification 
was based on thoughts that in the first year the patient was still considered ill and the following year was in recovery stage, so that the patient could be expected to go to school regularly.

Duration of disease was indirectly assumed to affect school performance, because duration of illness has been thought to influence the severity of valvular and myocardial defects affecting the severity of disease. Recent RHD presumably would affect the severity of disease and school performance. In bivariate and logistic regression analyses, there was no relation between duration of disease and educational achievement $(p=0.349)$, absent of school $(p=0.1853)$, dropouts $(p=0.424)$, schooling performance $(p=0.35)$.

\section{Educational achievement prior to illness}

Neither literature nor study reports existed in discussing educational achievement prior to illness in students with RHD. In bivariate analysis premorbid educational achievemen and educational achievement at the time of illness were not significantly associated $(p=0.362)$. Sinular results were found between educational achievement prior to illness and absent of school $(p=0.119)$, dropouts $(p=0.925)$, school performance $(\mathrm{p}=0.210)$. The same applies to logistic regression analysis (Table 4) that showed that educational achievement prior to illness did not relate to schooling performance $(\mathrm{p}=0.752)$.

\section{Socio-economic status of the family}

There was no significant association, between socioeconomic status of family and educational achievement, absent of school, dropouts and school performance. This finding was different with the results in Wahab's ${ }^{17}$ study showing that patients with low socio-economic status were brought to their doctors when their symptoms had been severe, while those with high socio-economic status were brought to their doctors earlier that it was presumed in causing good school performance.

\section{Parental educational level}

Parental educational level, was divided into 2 groups, consistent with Wahab's ${ }^{17}$ study and state compulsory education program of 9 years, $<$ JHS group and $>$ SHS group.
Maternal and paternal education levels are related to children's health status, in the sense that the higher the educational level the greater the parental understanding of children's health, ${ }^{15}$ and of course, patients' performance including better school performance.

In our series bivariate analysis showed significant association of parental educational level and educational achievement $(p=0.009)$. On the other side this study showed there was no relationship between parental educational level and absent of school $(p=0.537)$, dropouts $(p=0.102)$, school performance $(p=0.083)$. This was probably due to the lack of direct influence parental educational and school and dropouts. However, logistic regression analysis (Table 4) showed that parental educational level $(p=0.0507)$ has relationship with school performance.

\section{Number of children in the family}

Large family would need more time to deal with its children, even greater expenses for living and treatment that it was thought that the greater the number of children the children's care was more ignored, ${ }^{17}$ and might cause negative impacts on students performance contracting RHD.

Bivariate and logistic regression analyses the showed that number of children in the family did not relate to absent of school $(\mathrm{p}=0.316)$, dropouts $(p=0.438)$ and school performance $(p=0.441)$.

\section{Severity of the disease}

The severity of RHD is a highly important determinant among all factors affecting school performance. ${ }^{9}$ In the previous study it was reported that out of 61 patients with MI, on 4-37 years followup, 56 patients remained in mild disease, while the other 5 patients developed severe complications ${ }^{13}$ causing possible poor performance. Not much different from previous study, that severity of the disease relate to educational achievement $(\mathrm{p}=0.05)$, absent of school $(p=0.002)$, dropouts $(p=0.006)$, and school performance $(p=0.0018)$.

Based on the present study there was an impression that among the three independent variables (parental educational level, number of children in the family and severity of the disease), the severity of disease greatly affected school performance. Whereas in logistic regression analysis, as seen in Table 4 , the se- 
verity of disease $(p=0.0010)$ and parental educational level $(p=0.0507)$ indicated great influence on schooling performance. In summary, based on analysis.

In the present study, on assessing the influence of RHD upon school performance of 80 subject studied the following conclusions can be drawn: 1.The severity of disease and parental education level showed effect on schooling performance. ${ }^{2}$. Independent variables such as age, sex, duration of disease, premorbid educational achievement, socio-economic level of the family and number of children in family did not revealed effect on schooling performance.

\section{References}

1. World Health Organization. Rheumatic fever and rheumatic heart disease. WHO Techn Ser 1988; 764-5.

2. Hanafiah A. Is rheumatic heart disease an important heath problem in Indonesia? World Health Organization. New Delhi. Nov. 21-23,1979.

3. Madiyono B. Epidemiologi penyakit jantung reumatik di Indonesia. J Kardiol Indon 1995; 20:25-6.

4. Madiyono B. Epidemiologi penyakit jantung reumatik di Indonesia. Presented at Simposium Demam Reumatik dan PenyakitJantung Reumatik, Konggres Perhimpunan Kardiologi Indonesia ke VII (KOPERKI VII), Bandung 26-29 Juni 1994.

5. Achutti AA, Achutti VR. Epidemilogy of rheumatic fever in the developing world. Cardiol Young 1992; 206-15.

6. Sastrosubroto $\mathrm{H}$. Epidemiologi demam reumatik dan penyakit jantung reumatik. Naskah lengkap lokakarya masalah demam reumatik dan penyakit jantung reumatik di Indonesia, Jakarta, 19-20 November 1988.

7. The first Southeast Asian Rheumatic Fever and Rheumatic Heart Disease Prevention Conference: Japan Heart Foundation, Hakone, 1973.
8. Taranta A, Markowitz M. Diagnosis rheumatic fever. 2nd ed. London: Kluwer academic Publisher; 1989. p. 1-68.

9. Madiyono B, Sastroasmoro S. Demam reumatik dan penyakit jantung reumatik. In: Markum $\mathrm{AH}$, et al, editors. Buku Ajar Ilmu Kesehatan Anak. Jakarta: Balai Penerbit FKUI; 1991. p. 599-614.

10. Wahab AS. Penyakit jantung reumatik. In: Sastroasmoro S, Madiyono B, editors. Buku ajar kardiologi anak. Jakarta: Binarupa Aksara; 1994. p. 317-44

11. Kaplan S. Chronic rheumatic heart disease. In: Adams, Emanoulidies, editors. Moss-Adam Heart disease in infant, children and adolescent. 3rd ed. Baltimore: Williams \& Wilkins; 1983. p. 552-65.

12. Sutandar H. Riwayat perjalanan penyakit demam reumatik dan penyakit jantung reumatik. Kumpulan makalah lengkap Simposium demam reumatik dan penyakit jantung reumatik, Jakarta; 1984. p. 13-23.

13. Walker CHM. Rheumatic Heart disease. Practitioner, Feb,1970:225-37

14. Rustika, Salan R, Warsa CH. Prevalens infeksi streptokokus, demam reumatik dan penyakit jantung reumatik di Kecamatan Senen Jakarta Pusat 1992-1993. Pusat Penelitian Penyakit Tidak Menular. Badan Penelitian dan Pengembangan Kesehatan Departemen Kesehatan RI.

15. Markowitz M, The decline of rheumatic fever: Role of medical intervention. Lews W. Wannamaker Memarial Lecture. J Pediatr 1985; 106:545-50.

16. Wahab AS. Demam reumatik dan kelainan jantung reumatik pada anak. Faktor-faktor yang mempengaruhi kesetiaan usaha pencegahan sekunder [dissertation]. Yogyakarta: Universitas Gajah Mada; 1980.

17. Oesman IN, Firmansyah A, Setiamiharja WH, Compliance of secondary prophylaxis in patiens with rheumatics fever and rheumatic heart disease. Indones J Pediatr Cardiol 1999; 1:5-9. 